\title{
The incidence of hereditary disease in man
}

\author{
PATRICIA ASH, J. VENNART, AND C. O. CARTER \\ From the MRC Radiobiology Unit, and MRC Clinical Genetics Unit, Harwell, Didcot, Oxon
}

The Medical Research Council's Committee on Protection against Ionising Radiations (PIRC) has the responsibility for advising Council on the risks of ionising radiations. PIRC last reported on the risk of radiation-induced hereditary disease in 1960 when Council published its second report on 'The Hazards to Man of Nuclear and Allied Radiations'. Any new estimate of this risk would require up-to-date information on the natural incidence of hereditary diseases in man. Therefore PIRC decided to organise a forum meeting at which could be discussed the frequencies of hereditary disease, their severity, the extent to which they are maintained by new mutations, and their transmissibility. The meeting was held at the Council's Offices on 16 March 1976. It was chaired by Professor P. E. Polani, FRS, and attended by 35 people (Appendix). Abridged versions of the seven papers presented at the forum are printed in the following pages; the conclusions reached during discussion were as follows.

To estimate the risk of hereditary damage from ionising radiation, the genetically determined diseases to be considered are those whose frequency is closely linked to the mutation rate as estimated using the incidence in live-births. These disorders, most of which are serious, include those arising from chromosome number anomalies (about 5 per 1000), the dominant monogenic disorders (about 7 per 1000), and some of those resulting from chromosomal structural rearrangements (about 2 per 1000), giving a total frequency of about 14 per thousand live births. The concept that a dose of radiation might double the natural mutation frequency might be applied to such disorders.

If for chronic irradiations with $X$ - or $\gamma$-rays the doubling dose is $100 \mathrm{rad}, 140$ cases of these hereditary diseases would occur in one million people of prereproductive age exposed to $1 \mathrm{rad}$.

The question of whether multifactorial disorders should be considered in assessing the risks of ionising radiations is one of semantics, for if multifactorial diseases are maintained by mutations, they are essentially monogenic. For example, there are genetic and environmental components in the aetiology of ischaemic heart disease and a fraction of the total incidence is actually maintained by new mutation because this fraction is a monogenic disease, for example so-called essential familial hypercholesterolaemia. With regard to polygenic conditions in general, there is still dispute over the extent to which an increased mutation rate would affect their frequency. If they are largely maintained by new mutation it would not be unrealistic to employ the doubling dose concept.

The dominant monogenic conditions have special importance in assessing radiation effects. The relation between mutation rate and birth frequency is relatively direct, the theoretical equilibrium birth frequency being the product of twice the mutation rate and the mean persistence in terms of generations of each mutant gene. Any increase in mutation rate will be reflected at once by an increase in the birth frequency of fresh cases of such dominant conditions born to unaffected parents. Recessive monogenic conditions must also be considered. However, many believe that the more frequent of these diseases are (or were recently) maintained at their frequency level by heterozygous advantage rather than by new mutations. Moreover, the interval between the occurrence of a recessive mutation in a gene and the birth of the affected subject may be lengthy-centuries or even millenia. It is now becoming possible to visualise ways of controlling the frequency of recessive gene disorders, that is the future carriers will be identified and where appropriate offered prenatal screening. Therefore, in the future the incidence of recessive gene disorders is likely to change.

\section{Reference}

Medical Research Council (1960). The Hazards to Man of Nuclear and Allied Radiations, 2nd Report, Cmnd. 1225. HMSO, London.

Requests for reprints to Dr J. Vennart, MRC Radiobiology Unit, Harwell, Didcot, Oxon OX11 ORD. 
List of Participants at the Radiobiology Forum on the Incidence of Hereditary Disease in Man

Dr Eva Alberman, Paediatric Research Unit, Prince Philip Laboratories, Guy's Hospital Medical School, London SE1 9RT.

Dr Patricia J. D. Ash, MRC Radiobiology Unit, Harwell, Oxon, OX11 ORD.

Dr K. F. Baverstock, MRC Radiobiology Unit, Harwell, Oxon, OX11 ORD.

Professor C. O. Carter, MRC Clinical Genetics Unit, Institute of Chld Health, 30 Guilford Street, London WC1.

Dr B. M. Cattanach, MRC Radiobiology Unit, Harwell, Oxon, OX11 ORD.

Dr Valerie A. Cowie, Queen Mary's Hospital for Children, Carshalton, Surrey SM5 4NR.

Dr M. R. Creasy, Paediatric Research Unit, Prince Philip Laboratories, Guy's Hospital Medical School, London SE1 9RT.

Dr Julie Denekamp, Gray Laboratory, Mount Vernon Hospital, Northwood, Middlesex.

Dr G. W. Dolphin, National Radiological Protection Board, Harwell, Oxon, OX11 ORQ.

Dr G. J. Draper, Childhood Cancer Research group, Old Radcliffe Observatory, Woodstock Road, Oxford OX2 61N.

Professor J. H. Edwards, Infant Development Unit, Birmingham Maternity Hospital, Birmingham 15.

Professor H. J. Evans, MRC Clinical and Population Cytogenetics Unit, Western General Hospital, Crewe Road, Edinburgh EH4 2XU.

Dr M. Fisher, Medical Research Council, 20 Park Crescent, London W1N 4AL.

Dr K. I. Gibson, Medical Research Council, 20 Park Crescent, London W1N 4AL.

Dr I. Leck, University of Manchester, Regional Cancer Epidemiology Unit, Christie Hospital and Holt Radium Institute, Withington, Manchester M20 9BX.

Dr D. Lloyd, National Radiological Protection Board, Harwell, Oxon.

Dr Mary F. Lyon, MRC Radiobiology Unit, Harwell, Oxon. OX11 ORD.

Dr G. A. Machin, Department of Pathology, Edin- burgh University, 1 Crawfurd Road, Edinburgh,,$\stackrel{\mathbb{\Phi}}{=}$ EH16 5PQ.

Dr R. H. Mole, MRC Radiobiology Unit, Harwell, $\overrightarrow{\vec{A}}$ Oxon. OX11 ORD.

Professor N. Nevin, Medical Genetics Department, Queen's University, Belfast.

Professor P. Oftedal, Institute of General Genetics, $\overrightarrow{\widehat{\phi}}$ University of Oslo, PO Box 1031, Blindern, Oslo 3, Norway.

Sir Edward E. Pochin, National Radiological Pro- $\overrightarrow{0}$ tection Board, Harwell Oxon.

Professor P. E. Polani, Paediatric Research Unit, $\vec{\omega}$ Prince Philip Laboratories, Guy's Hospital Medical School, London SE1 9RT.

Professor G. Rose, St Mary's Hospital Medical $\vec{A}$ School, Norfolk Place, London W2.

Dr Doreen Rothman, Department of Health and Social Security, Hannibal House, Elephant ando Castle, London SE1 6TE.

Dr K. Sankaranarayanan, Department of RadiationGenetics and Chemical Mutagenesis, State University of Leiden, Sylvius Laboratories, Was-0 senaarseweg 72, Leiden, Holland.

Dr D. Scott, Paterson Laboratories, Christie Hospital and Holt Radium Institute, Manchester, M20 9BX.

Dr A. G Searle, MRC Radiobiology Unit, Harwell, Oxon, OX11 ORD.

Dr J. Shields, Institute of Psychiatry, De Crespigny흥 Park, London SE5 8AF.

Dr Joan Slack, MRC Clinical Genetics Unit, Institute $\stackrel{\odot}{\odot}$ of Child Health, 30 Guilford Street, London $\overrightarrow{\vec{P}}$ WC1N $1 E H$.

Professor R. W. Smithells, Department of Paediatrics, University of Leeds, 27 Blundell Street, Leeds LS1 3ET.

Dr F. D. Sowby International Commission on Radiorô logical Protection, Clifton Avenue, Sutton, Surrey SM2 5PU.

Professor F. W. Spiers, Department of Medical Physics, Cookridge Hospital, Leeds LS16 6QB

Dr A. C. Stevenson, Laboratories, Royal Northern 을 Infirmary, Inverness.

Dr J. Vennart, MRC Radiobiology Unit, Harwell, Oxon, OX11 ORD. 